\title{
AGGRESSIVE BEHAVIOR: REVISITING THE INFLUENCE OF PARENTING STYLES AND RELIGIOUS COMMITMENT AMONG YOUTH (A STUDY OF SOUTH PUNJAB PAKISTAN)
}

\author{
Muhammad Umair Ashraf', Yasir Aleem Fatiana², Sanan Waheed Khan³, Muhammad Asif ${ }^{4}$, Asfa \\ Ashraf 5 \\ Ph.D Scholar (Sociology), Ghazali Shafie Graduate School of Government, Universiti Utara Malaysia ${ }^{1,}$ \\ ${ }^{4}$ umairgujar359@gmail.com, asifnsf@gmail.com
}

PhD Scholar (Law) School of Law, Universiti Utara Malaysia ${ }^{2}$ Corresponding Email: yasir.aleem@ hotmail.com $\mathrm{PhD}$ Scholar, Department of Communication Studies, FBMK, Universiti Putra

Malaysia ${ }^{3}$ sannankharal@gmail.com

M.Phil Scholar (Sociology),Bahauddin Zakariya University, Multan ${ }^{5}$

asfaashraf85@gmail.com

\begin{abstract}
In times negative parenting practices are the main risk factor for antisocial aggressive behavior among youth, howeverin this context, there is dearth of research studies that investigates the influence of parenting styles and religious commitment among aggressive behavior of youth. Correspondingly, the purpose of this research to examine the influence of parenting styles and religious commitment on aggressive behavior among youth of south Punjab, Pakistan. For this purpose, a cross-sectional research was designed.A totalN=381 male and females' students from three renowned public sector universities of south Punjab were targeted through multistage sampling technique. However, the validation of adapted scales has been analyzed by employing confirmatory factor analysis (CFA), however, structural equation modeling (SEM) method has been used for hypotheses testing. The findings showed that authoritative parenting styles has significant negative relationship with aggressive behavior, in contrast, permissive and authoritarian parenting style have significant positive relationship with aggressive behavior. Additionally, religious commitment has significant negative relationship with aggressive behavior.This study concluded that permissive and authoritarian parenting styles are the influential factor in the development of aggressive behavior, while religious commitment and authoritative parenting style are negatively influence on antisocial aggressive behavior.
\end{abstract}

KEYWORDS: Aggressive Behavior, Authoritative, Authoritarian, Permissive, Parenting Styles, Religious Commitment.

Article Received: 10 August 2020, Revised: 25 October 2020, Accepted: 18 November 2020

\section{INTRODUCTION}

Aggressive behavior is the behavior whose repercussion badly affects the social relationships of a human being in a society. This violation of socially acceptable behavior includes; offensive gossips, social rejection, (Boxer \& Goldstein, 2012) bullying (Gomez-Ortiz et al., 2014), communal embarrassment, physical violence (Clark, Dahlen \& Nicholson, 2015), disruptive behavior (Stormshak et al., 2000), rebelliousness and disobeying the others (Alizadeh, Talib \& Abdullah, 2011). In United States, according to a report of National center for educational statistics (2016) approximately $33 \%$ of the students found to be suspect of various acts of violation. Of these $33 \% 13 \%$ students have made fun of the others by calling them with bad names and insulting them in public. $12 \%$ have been suspected to spread rumors, $5 \%$ were involved in physical humiliation $5 \%$ are disqualified from the activities on tenacity. These acts are noticed in $34 \%$ classrooms, $22 \%$ cafeterias,
$19 \%$ school's playground, $10 \%$ transport and $9 \%$ in toilets.

According to center for disease control (2017) students who tend to express aggressive behavior have higher tendency to face sleeplessness, poor institutional regulation, anxiety and depression. In this way, students who are engaged in bullying and other unstandardized activities have higher risk of psychological illness $19 \%$ of these students have poor self-belief which can disturb their family ties and peer group bonding. Not only such aggressive behavior disturbs their personality and their primary relations but also such aggression can be harmful for their physical health and well-being as well (Gini \&Pozzoli, 2013). Growing body of knowledge has indicated various determiners which are the cause of aggressiveness in youth. For instance,Ojo (2015) demonstrated determiners of interpersonal aggression with respect to an individual's family environment, parental harsh behavior, broken homes, physical punishment, 
death of a beloved one, poverty, financial problems and more probably absence of parental bonding (Clare, 2006). Henceforth, can say that parenting styles plays a significant role in developing a child's behavioral manifestation (Ashraf et al., 2019).

Generally, Baumrind's (1966) work on parenting styles is said to be the pioneer in studying parental dimensions based on parental responsiveness and parental demandingness. These styles have been nominated as authoritative, permissive and authoritarian parenting style (Hoskins, 2014). Outcomes of various studies indicated the association between parenting styles and child's behavioral outcomes (Sangawi, Adams \&Reissland, 2015; Stevens et al., 2007; Mulvaney \&Mebert, 2007). Massive literature guided that of all three parenting styles authoritative parents are highest in responsiveness and demandingness. Children of these parents are less likely to involve in violating societal norms and values (Hoskins, 2014). Contrary, authoritarian parenting style is opposite to authoritative parenting style. Batool (2013) described the concerning point by following the assumptions of Bandura's social learning theory which speculated that children learn by imitating their parents. Children may model the aggression and authoritative behavior of their parents in controlling them. Under such circumstances, children tend to adopt physical or verbal aggressive mechanism to get control over a certain state of affairs (Bandura, 1989). In comparison to above both permissive parenting style comprises low demandingness and low responsiveness. It has been said that children of these parents are less sociable and weak in social relationships (Rizvi \& Najam, 2015).

Despite all nowadays researchers have main concern in appreciative religious commitment on youth's aggressive behavior. Growing body of literature has explained the influence of religious commitment in reducing aggressive behavior. Pirutinsky (2014) and Massarwi, Kassabri and Eseed (2019) focused on religious activities discourage the involvement in delinquent activities. Researchers have argued Hirschi's social control theory explained that many people do not get involved into deviant activities because of their strong religious bond. People who does not follow the religious values are more likely to attract towards breaking that rules which should be followed (Desmon et al., 2011). In Pakistan, Ashraf et al. (2019) investigated the role of parenting practices in establishing violent behavior among youth. Similarly, Shagufta et al. (2015) discovered the etiological role of peer group, disruptive behavior, bullying in developing violent behavior. A report by Punjab bureau of statistics on crime and education (2018) there were 4017 cases of murder, 11425 cases of Burglary, 34572 cases of theft and 793 cases of dacoits in Punjab. As far as aggressive behavior later can be converted into crime that could not only severely deteriorate the smooth running of society but family and social institutions as well. Henceforth, the principle objective of this research is investigating the relationship, direction and consistency of parenting styles such as, permissive, authoritarian, authoritative and religious commitment on youth's anti-social aggressivebehavior in south Punjab Pakistan. Prior researches have been conducted on the population of western context and a recent study of Massarwi, Kassabri and Eseed (2019) stated there is a paucity of literature on these particular aspects in non-western culture. Therefore, this study is helpful for the literature in this regard.

\subsection{Research Objectives}

(1) To investigate the parenting styles (authoritative, authoritarian, Permissive) and its effect on aggressive behavior among youth.

(2) To analyze the religious commitment and its effect on aggressive behavior among youth.

\subsection{Theoretical Framework and Hypothetical Model}

According to the assumptions of Social Control Theory byHirschi (1969) postulated four imperative dimensions in which he described controlling mechanism of deviance. This theory stated four imperative mechanism i.e. attachment with parents and peer group can reduce the chances for a person to get involved into deviancy, while commitment comprises career aspiration and educational determination would lead to serve time and energy in making aspiration into reality, even though involvement as everyone know " Empty mind is devil's workshop" involvement in positive activities that could improve existing bonds with others spreads positive vibes and people would less likely to be involved in anti-social activities and lastly belief in societal norms and values can condense the risk of being involved into deviancy. If we consider this theory of social control with respect to context of current study.

\subsubsection{Authoritative Parenting Style and Aggressive Behavior}

When attachment is categorized as parental attachment it is put forwarded that social control can be seen via parental attachment; youngster's intimacy and interaction with their parents. There has been a negative relationship of parenting styles 
such as authoritative with youth's aggressive behavior and deviancy. Brannigan et al. (2002) found that boys who had experienced a smaller amount of supervision by their parents displayed aggressive behavior. Similarly, Hinrich et al. (2005) found that strong parent-child bonds can increase child's connectedness in educational activities and lessen the chances of attraction towards deviant activities. Furthermore, Chapple (2003) discovered that children who faced violence by their parents tend to display more aggressive behavior. Kawabata et al. (2011) discussed that children whose parents are polite and highly responsive towards them develop expressive warmth and parade lower aggression in terms of social and personal relationships. In such a way, it can be said that parents who are friendly with their children tend to build a strong positive rapport in child's cognitive development. Children would be more likely to share their problems with them and adopt less negativity.

Hla: There is a significant negative relationship between authoritative parenting style and aggressive behavior of youth.

\subsubsection{Authoritarian Parenting Style and Aggressive Behavior}

Miklikowska (2016) stated that parental politeness can increase the chances for a child to develop positive behavior and spread positive vibes but on the other side parental restrictions and imposition could lead to development of negative behaviors among youth. Gomez-Ortiz et al. (2014) discussed that parents who are highly demanding, punitive and strict towards their children positively influence the behavioral manifestation of their children. In such circumstances, authoritarian parenting style is positively associated with aggressive behavior of youth. Precisely, traits such as physical punishment and highly demanding milieu found to be connected with increased aggressiveness among children, poor sympathy and diminished prosocial attitude among children (Kuppens et al., 2009) and bullying among youngsters. As far as, poor parental recognition and engrossment, poor sovereignty and prerequisite rewards. All these practices of authoritarian parenting style have been found to be linked with developing aggressiveness among children (Gray \& Steinberg, 1999).

H1b: There is a significant positive relationship between authoritarian parenting style and aggressive behavior of youth.

\subsubsection{Permissive Parenting Style and Aggressive behavior}

When it comes to permissive parenting style; these parents are those who are highest in responsive and lowest in demanding to their children (Baumrind, 1966). These parents set their children free to do whatever they want to do in life. As a result, children face many difficulties in their social and personal relationships. Henceforth, lack of parental guidance and monitoring leads them to indulge in violating societal values. There are chances for these children to start using drugs, cigarette and poor academic progress (Ashraf et al., 2019). Furthermore, Clart, Dahlen and Nicholson (2015) discussed that permissive parenting style is an important determinant of child's aggressive behavior because these children have lack of knowledge regarding societal norms and values. They do not have anyone to guide them right way (Sandstrom, 2007). Findings of Smack, Kushner and Tackett (2015) indicated that children who receive poor control and monitoring from their parents are more likely to develop aggressiveness as a part of their personality.

H1c: There is a significant positive relationship between permissive parenting style and aggressive behavior of youth.

\subsubsection{Religious Commitment and Aggressive Behavior}

After parental attachment religiosity has been found to be most effective in reducing aggression because aggression is forbidden in every religion. Those people who daily visit their worship places and have strong belief in religious values less adopt aggressive behavior (Johnson et al.2001; Resnick et al., 2004). Furthermore, if we focus on parental religious involvement. In such situation Khan et al. (2019) found that parental religious commitment would be completely transferred to child's religious prejudices and these religious prejudices would be converted into rigid religious commitment. As a result, youngsters tend to have less victims of anxiety and depression and they there would be the less risk for a youngster to adopt aggressive behavior (Sanders et al., 2015). In the same way, a recent study conducted by Massarwi, Kassabri and Eseed (2019) found a negative relationship between religious commitment and aggressive behavior in the light of Hirschi's theory of social control (1969). Henceforth, we can assume that social bonds and religious commitment could help us all to stay away from anti-social behaviors. Can say that despite of having the company of deviant people a religious person would not attract towards anti-social activities and would not adopt aggressive behavior at all.

H2: There is a significant negative relationship between religious commitment and aggressive behavior of youth. 


\subsection{Conceptual Model of the Study}

Figure 1 gives the conceptual model developed for this research, based on the theoretical and empirical support.

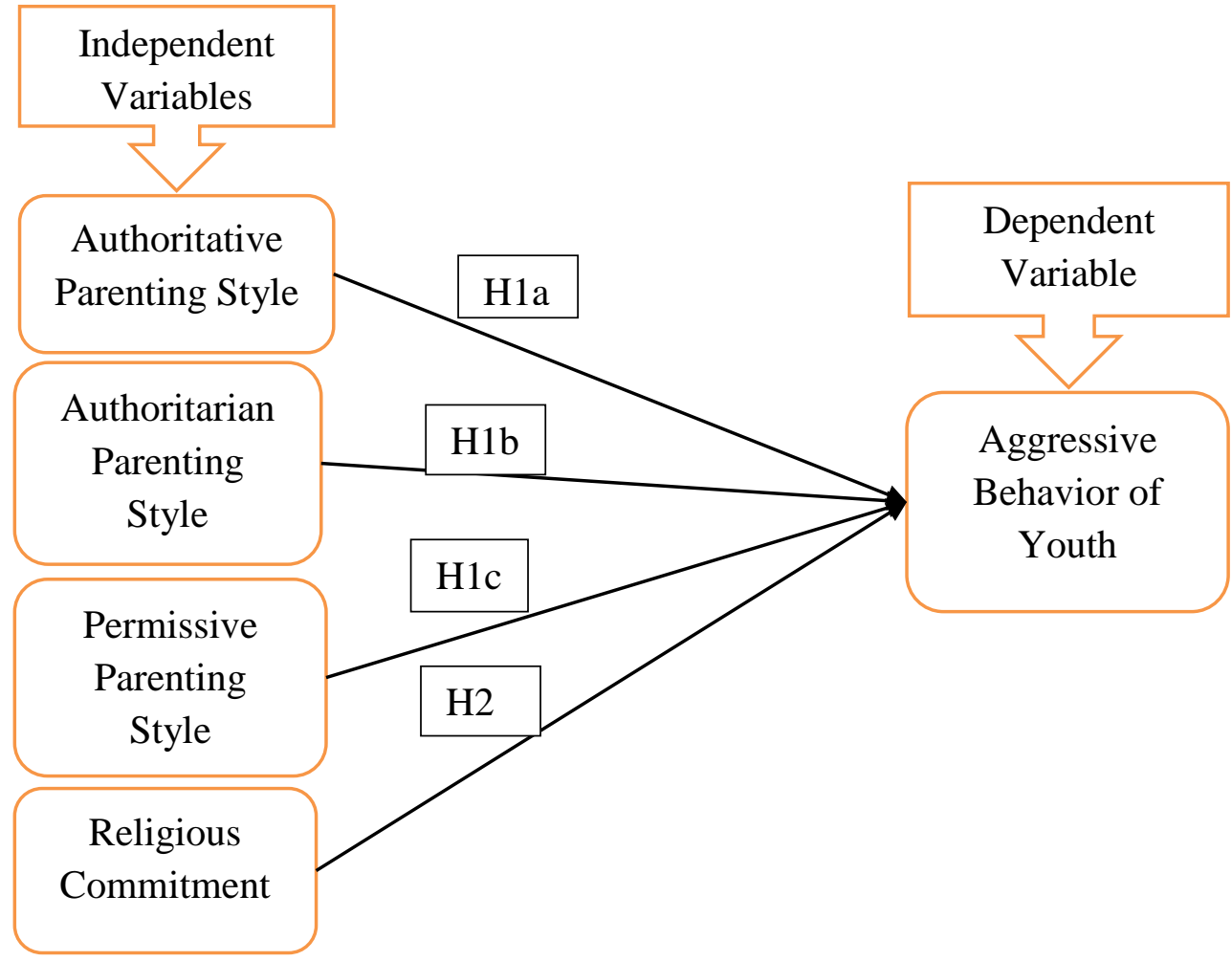

Figure 1: Conceptual Model

\subsection{Material and Methods}

The university structural pathology indicated that there are 3 public universities in south Punjab with the student population i.e. 43153 students. By focusing these pathological consideration circumstances, the principal author designed current research.

\subsection{Participants and Procedure}

A total number of $\mathrm{N}=381$ students (170 male students and 211 female students) had participated in the study from $n=3$ public universities of study locale. Those participants who had passed at least one semester of BS, Masters and M.Phil. Presently, registered for one month were approached. Firstly, researcher had distributed consent letter in their classes for getting the permission to participate in the study. Researcher had used multi-stage sampling technique in order to confirm prospect, generalizability and accuracy of responses. At first stage, researchers randomly selected three districts from thirty-six districts of Punjab, at the second stage, researchers selected one public university from all the universities in each district, at the last stage, researchers selected the students through simple random sampling technique by following de-facto approach method. Total population was
43153 and researcher had drawn sample size of 381 by using Krejcie and Morgan table (1970) for sample size determination.

\subsection{Measurement}

Students reported aggressive behavior through dual factors such as parenting styles and religious commitment. For this purpose, researchers had divided questionnaire in three major parts i.e. (a) socio-economic status and demographic characteristics (b) predictor variables (parenting styles and religious commitment aggressive behavior) (c) outcome variable (aggressive behavior). For measuring the socio-economic status and demographic characteristics researchers used questions of age, gender, level of education, parental education, residence, family type and family income: retrieved from Pakistan Social and Living Standard Measurement (PSLSM) (2013-14).

Consequently, parenting styles and religious commitment were used as independent variables. Researchers was adapted Parenting Authority Questionnaire (PAQ) by Buri (1991) to assess parenting styles. This scale was comprised of 30items based on three mechanisms including a comprised of authoritative (10-items), permissive style (10-items) and authoritarian (10-items). This 
scale with five-point Likert scale ranges form (1= strongly disagree to $5=$ strongly agree) respectively. While religious commitment scales developed by Worthington et al. (2003) was adapted to measure the respondent's religious commitment. This scale was consisted of 10 items rated on five-point Likert scale ranges form (1= Not at all to $5=$ totally). In the consequent section, researchers adapted aggression scale developed by Orpinas and Frankowski (2001) to measure the student's aggressive behavior. This scale was consisted of 11 items rated on 5-point Likert scale ranges from (1=strongly disagree, 5=strongly agree) respectively.

\subsection{Data Analysis}

For coding, transforming and recoding the variables data was analyzed by using SPSS-21. At first step, evaluation of subject's socio-economic status and demographic characteristics researchers had used frequency and percentage. Afterwards, the relationship between independent variables and criterion variable i.e. independent (authoritarian + authoritative + permissive+ religious commitment $\rightarrow$ aggressive behavior) was evaluated by using structural equation modeling (SEM).

\subsection{Descriptive Statistics}

The Below-mentioned tables 1 describes the socioeconomic status and demographic characteristics of the subjects participated in current study. Of these $\mathrm{N}=318$ subjects $54.6 \%$ (208) were the age of $18-22$ year, maximum of the subjects $55.4 \%$ (211) were female, majority of the subjects $60.9 \%$ (232) reported that they were the students of masters, $22.3 \%$ (85) reported that their father had done graduation, $19.4 \%$ (74) reported their mother had complete primary education, $58.3 \% \quad$ (222) mentioned that they belong to urban area, 53.8\% (205) stated they were living in joint family system and $27.3 \%$ (104) mentioned their monthly family income 71000-100000 PKR.

Table. 1

Demographic Profileof the Respondents

\begin{tabular}{|c|c|c|}
\hline Variable & Categories & F (\%) \\
\hline \multicolumn{3}{|l|}{ Age } \\
\hline & $18-22$ & $208(54.6)$ \\
\hline & $23-26$ & $92(24.1)$ \\
\hline & $27-30$ & $81(21.3)$ \\
\hline \multicolumn{3}{|l|}{ Gender } \\
\hline & Male & $170(44.6)$ \\
\hline & Female & $211(55.4)$ \\
\hline \multicolumn{3}{|c|}{ Level of Education } \\
\hline & BS(Hons) & $139(36.5)$ \\
\hline & Master's & $232(60.9)$ \\
\hline & M.Phil. & $10(2.6)$ \\
\hline \multicolumn{3}{|c|}{ Father's Qualification } \\
\hline & Illiterate & $27(7.1)$ \\
\hline & Primary & $18(4.7)$ \\
\hline & Middle & $36(9.4)$ \\
\hline & Matriculation & $83(21.8)$ \\
\hline & Intermediate & $67(17.6)$ \\
\hline & Graduation & $85(22.3)$ \\
\hline & Master's & $53(13.9)$ \\
\hline & Other & $12(3.1)$ \\
\hline \multicolumn{3}{|c|}{ Mother's Qualification } \\
\hline & Illiterate & $62(16.3)$ \\
\hline & Primary & $74(19.4)$ \\
\hline & Middle & $53(13.9)$ \\
\hline & Matriculation & $60(15.7)$ \\
\hline & Intermediate & $29(7.6)$ \\
\hline & Graduation & $55(14.4)$ \\
\hline & Master's & $22(5.8)$ \\
\hline & Other & $26(6.8)$ \\
\hline \multicolumn{3}{|l|}{ Residence } \\
\hline & Rural & $159(41.7)$ \\
\hline & Urban & $222(58.3)$ \\
\hline
\end{tabular}


Family Income

$\begin{array}{cc}\text { Extended } & 66(17.3) \\ \text { Joint } & 205(53.8) \\ \text { Nuclear } & 110(28.9)\end{array}$

$\begin{array}{cc}10000-40000 \text { PKR } & 177(46.5) \\ 41000-70000 \text { PKR } & 70(18.4) \\ 71000-100000 \text { PKR } & 104(27.3) \\ 101000-130000 \text { PKR } & 25(6.6) \\ 131000 \text { and Above } & 5(1.3)\end{array}$

$\mathrm{N}=381 \mathrm{f}=$ frequency, $\%=$ percentage

\subsection{Inferential Statistics}

In this study research model was analyzed by used structural equation modeling Partial Least Squares (PLS-SEM), employing the Smart PLS 3.0 generation software (Ringle et al. 2015). As suggested two stage approach by Anderson \&Gerbing (1988), the measurement model was tested followed by structural equation model (SEM). The measurement model represents the relationship between latent constructs and its associated items, while the structural model examines the relationship between latent variables (Hair et al., 2017). In further, to test the common method bias the Harman's single factor was used because if any factor that explain the majority of variance (Podsakoff et al. 2012). The results of unrotated factor analysis revealed that the first factor explained the $(29.94 \%)$ of the total variance explained $(74.87 \%)$ which approved that $\mathrm{CMB}$ is not an issue in this study.

\subsection{Measurement Model}

As depicted table 2 the factor loading, composite reliability (CR) and average variance extract (AVE) of all variables that are used to measure the convergent validity. In line with Hair, Ringle, \&Sarstedt (2011) the rationality of a measurement construct is said to be convergent when items/ indicators loading high on (i.e., > 0.50) on their associated variables. As shown figure 2 and Table 2 , all the items were above the acceptable range. Moreover, convergent validity of variables is measured by $\mathrm{CR}$ and AVE values. The rule of thumb is that the values of AVE should be 0.50 or greater is considered acceptable (Barclay et al., 1995). The value of AVE for all constructs is above 0.50 , and $\mathrm{CR}$ is greater than 0.8 , representing that the convergent validity of all constructs has been established.

Table 2

Convergent Validity

\begin{tabular}{|c|c|c|c|c|c|}
\hline Constructs & Items & Loadings & $\mathbf{C A}$ & $\mathbf{C R}$ & AVE \\
\hline \multirow[t]{9}{*}{ Aggressive Behavior } & $\mathrm{AB} 1$ & 0.845 & 0.964 & 0.969 & 0.777 \\
\hline & $\mathrm{AB} 2$ & 0.858 & & & \\
\hline & $\mathrm{AB} 3$ & 0.914 & & & \\
\hline & $\mathrm{AB} 4$ & 0.888 & & & \\
\hline & AB6 & 0.855 & & & \\
\hline & $\mathrm{AB} 7$ & 0.894 & & & \\
\hline & $\mathrm{AB} 8$ & 0.905 & & & \\
\hline & AB9 & 0.884 & & & \\
\hline & $\mathrm{AB} 10$ & 0.888 & & & \\
\hline \multirow[t]{8}{*}{ Authoritative Style } & APS3 & 0.673 & 0.913 & 0.929 & 0.622 \\
\hline & APS4 & 0.765 & & & \\
\hline & APS5 & 0.786 & & & \\
\hline & APS6 & 0.785 & & & \\
\hline & APS7 & 0.815 & & & \\
\hline & APS8 & 0.841 & & & \\
\hline & APS9 & 0.800 & & & \\
\hline & APS10 & 0.829 & & & \\
\hline \multirow[t]{7}{*}{ Authoritarian Style } & AUPS1 & 0.736 & 0.922 & 0.935 & 0.616 \\
\hline & AUPS3 & 0.772 & & & \\
\hline & AUPS4 & 0.791 & & & \\
\hline & AUPS5 & 0.804 & & & \\
\hline & AUPS6 & 0.786 & & & \\
\hline & AUPS7 & 0.795 & & & \\
\hline & AUPS8 & 0.752 & & & \\
\hline
\end{tabular}




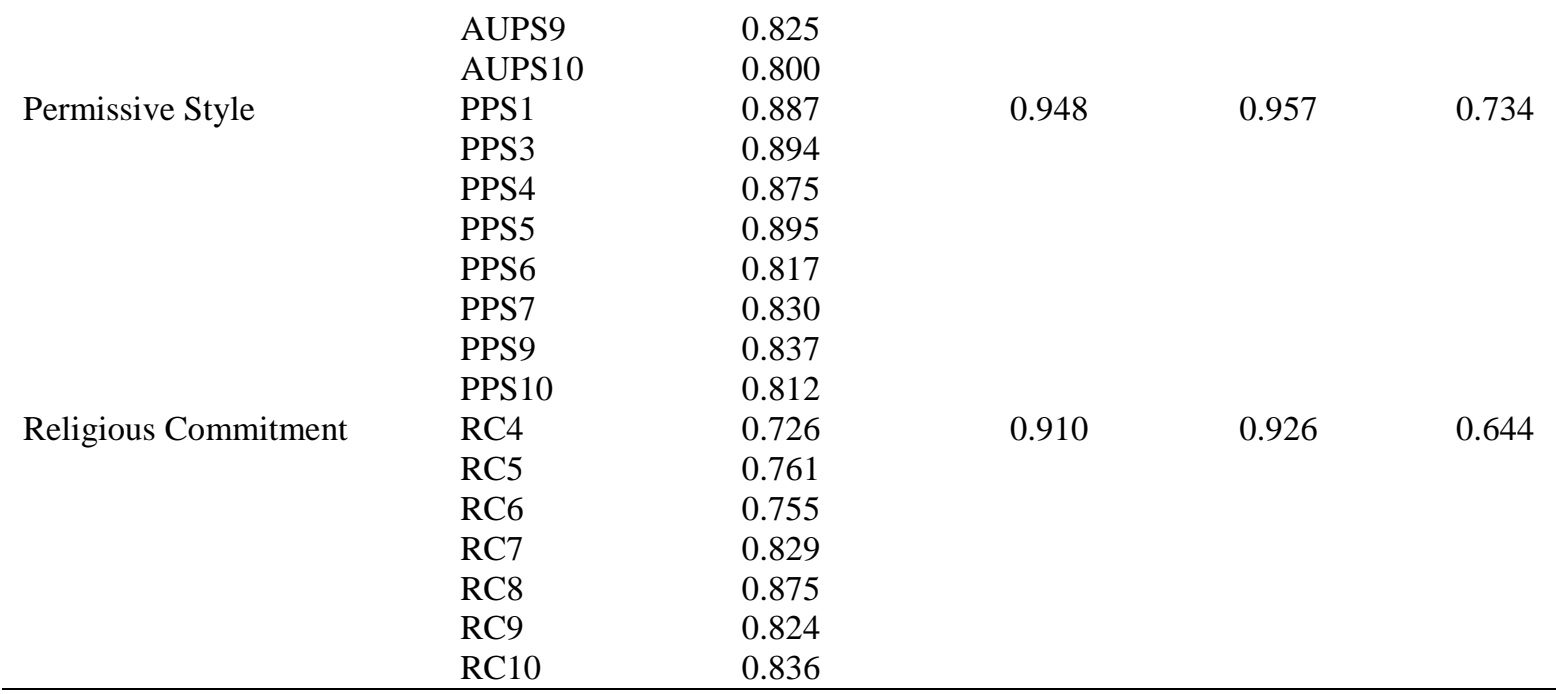

Note: $\mathrm{AB}=$ =' Aggressive Behavior, APS='Authoritative Parenting Style, AUPS='Authoritarian Parenting Style, $\mathrm{RC}=$ " Religious Commitment, $\mathrm{CA}=$ "' Cronbach's Alpha, $\mathrm{CR}=$ "' Composite Reliability, AVE="'Average Variance Extracted.

\subsection{Discriminant Validity}

The discriminant validity was evaluated based on two methods i.eFornell\&Larcker's (1981) criteria and heterotrait-monotrait (HTMT) Henseler et al. (2015). To establish the discriminant validity based on fornell - Lacker criteria, the square root of the
AVE for the constructs should be greater than its correlation with other variables in the model (Hair et al. 2017). Table 3 showed that the results of discriminant validity estimation of the constructs. Along the diagonal, the result depicted the square root of AVE for all constructs.

Table 3

Discriminant Validity Fornell - Larcker Method

\begin{tabular}{lccccc}
\hline Constructs & AB & AUPS & APS & PPS & RC \\
\hline AB & $\mathbf{0 . 8 8 2}$ & & & & \\
AUPS & 0.460 & $\mathbf{0 . 7 8 5}$ & $\mathbf{0 . 7 8 8}$ & & \\
APS & -0.127 & -0.020 & -0.038 & $\mathbf{0 . 8 5 6}$ & $\mathbf{0 . 8 0 2}$ \\
PPS & 0.441 & 0.787 & 0.060 & -0.016 & $\mathbf{0 . 0 3}$ \\
RC & -0.111 & -0.032 & .
\end{tabular}

Note: Diagonal values (bolded) are square root of the AVE while the off-diagonals are correlations. $\mathrm{AB}=$ "'Aggressive Behavior, APS="'Authoritative Parenting Style, AUPS="'Authoritarian Parenting Style, $\mathrm{RC}=$ ', Religious Commitment.

\subsection{Heterotrait - Monotrait Ratio}

Table 4 showed the HTMT ratio that is an effective approach to access the discriminant validity. Kline (2011) illustrated that HTMT ratio should be less than 0.85 to confirm the discriminant validity. As following this standard, entire values are less than 0.85 and confirmed that there is no issue regarding discriminant validity.

Table 3

Discriminant Validity Heterotrait - Monotrait Ratio Method

\begin{tabular}{llllll}
\hline Constructs & AB & AUPS & APS & PPS & RC \\
\hline AB & & & & \\
AUPS & 0.477 & & & \\
APS & 0.132 & 0.038 & 0.057 & 0.041 \\
PPS & 0.448 & 0.840 & 0.071 & \\
RC & 0.103 & 0.048 & & \\
\hline
\end{tabular}

Note: $\mathrm{AB}=$ "Aggressive Behavior, APS="Authoritative Parenting Style, AUPS="Authoritarian Parenting Style, RC=" Religious Commitment. 


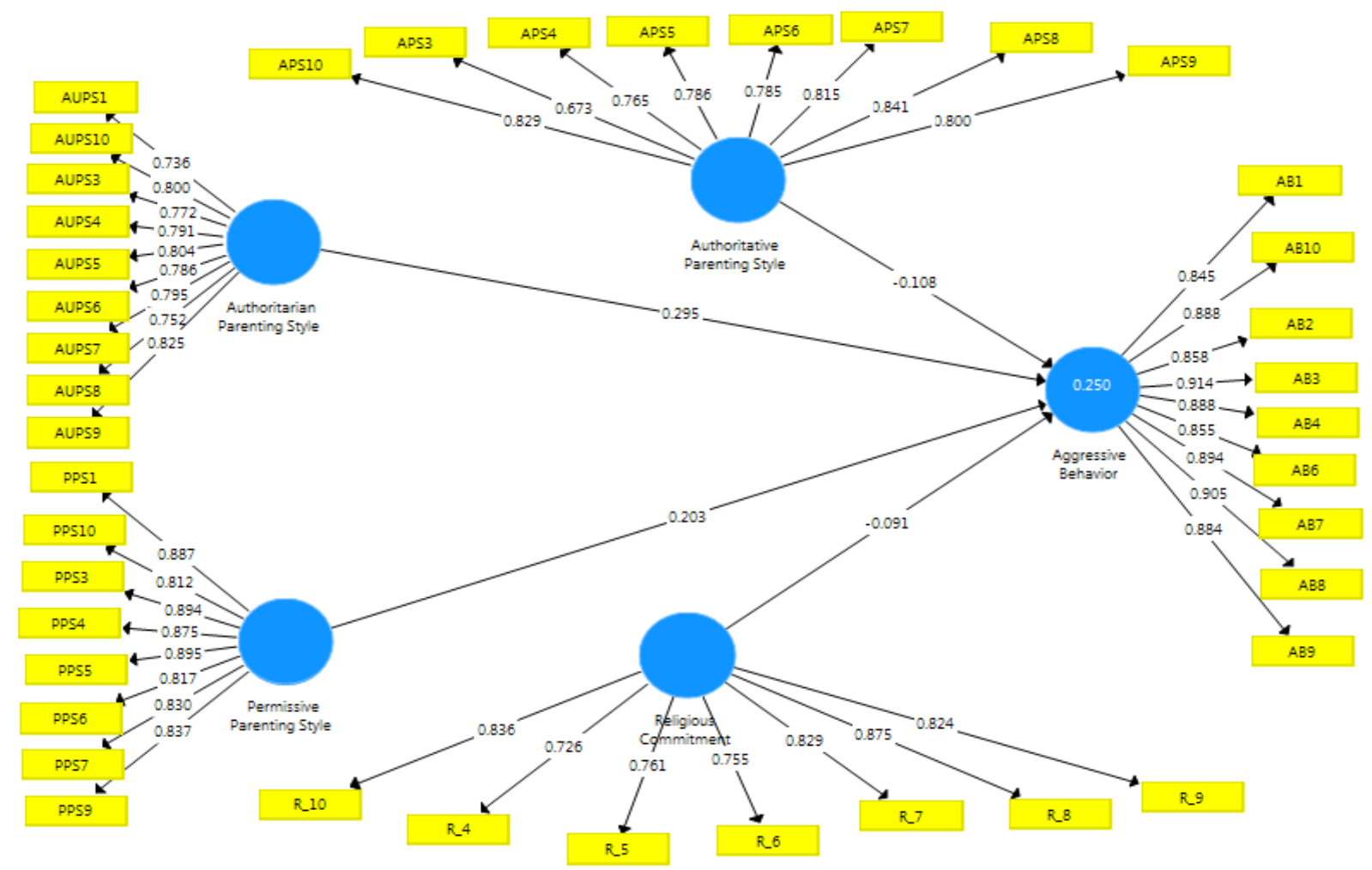

Figure 2: Measurement Model

\subsection{Structural Equation Modeling (SEM)}

The structural equation method techniques (SEM) was used to examine the relationship between variables. This study used a bootstrapping procedure to measure the significance of path coefficients with a resample of 5,000. Findings of this study revealed that authoritative parenting style has a significant and negative relationship with aggressive behavior among youth $(\beta=-0.108, \mathrm{t}=$ 2.754, p <0.003) and supported to H1a. On the other hand, authoritarian parenting style and permissive parenting styles have significant and positive relationship with aggressive behavior among youth $(\beta=0.295, \mathrm{t}=4.790, \mathrm{p}<0.000 ; \beta=$ $0.203, \mathrm{t}=3.412, \mathrm{p}<0.000$ ) and supported to $\mathrm{H} 1 \mathrm{~b}$ and, H1c. Additionally, religious commitment has significant and negative relationship with aggressive behavior among youth $(\beta=-0.091, \mathrm{t}=$ $2.184, \mathrm{p}<0.015$ ) and supported H2. Moreover, the effect size of all constructs is also showed in the table 5 . However, the $\mathrm{R}^{2}$ basically show the values of variance explained by exogenous latent variables (Hair et al., 2013). All the latent constructs mutually explained $(0.25 \%)$ of variance. This research also used a method to evaluate the predictive relevance of study model through employing blindfolding process (Stone, 1974). A cross-validated redundancy examine $\left(\mathrm{Q}^{2}\right)$ was employed to attain the predictive relevance (Hair et al., 2013). The $\mathrm{Q}^{2}$ for research model is greater than zero that highlighted predictive relevance. The findings of current study also depicted that there is no multicollinearity problem within data as VIF value is less than 5 as recommended by (Hair et al., 2011).

Table 5

Path Modeling/ Hypothesis Testing

\begin{tabular}{llccccccccc}
\hline H & Relationship & $\begin{array}{c}\text { Beta } \\
\text { value }\end{array}$ & $\begin{array}{c}\text { Std. } \\
\text { Error }\end{array}$ & $\begin{array}{c}\text { T- } \\
\text { value }\end{array}$ & $\begin{array}{c}\mathbf{p} \\
\text { value }\end{array}$ & Decision & $\mathbf{R}^{2}$ & $\mathbf{f}^{2}$ & VIF & $\mathbf{Q}^{2}$ \\
& & -0.108 & 0.039 & 2.754 & 0.003 & Supported & 0.250 & 0.016 & 1.005 & 0.176 \\
H1a & APS-> AB & 0.295 & 0.062 & 4.790 & 0.000 & Supported & & 0.044 & 2.630 & \\
H1b & AUPS-> AB & 0.203 & 0.060 & 3.412 & 0.000 & Supported & & 0.021 & 2.631 & \\
H1c & PPS-> AB & 0.091 & 0.042 & 2.184 & 0.015 & Supported & & 0.011 & 1.005 & \\
H2 & RC-> AB & -0.091 & &
\end{tabular}

Note: $\mathrm{AB}=$ ''Aggressive Behavior, APS='AAuthoritative Parenting Style, AUPS='A Authoritarian Parenting Style, $\mathrm{RC}=$ ', Religious Commitment. 


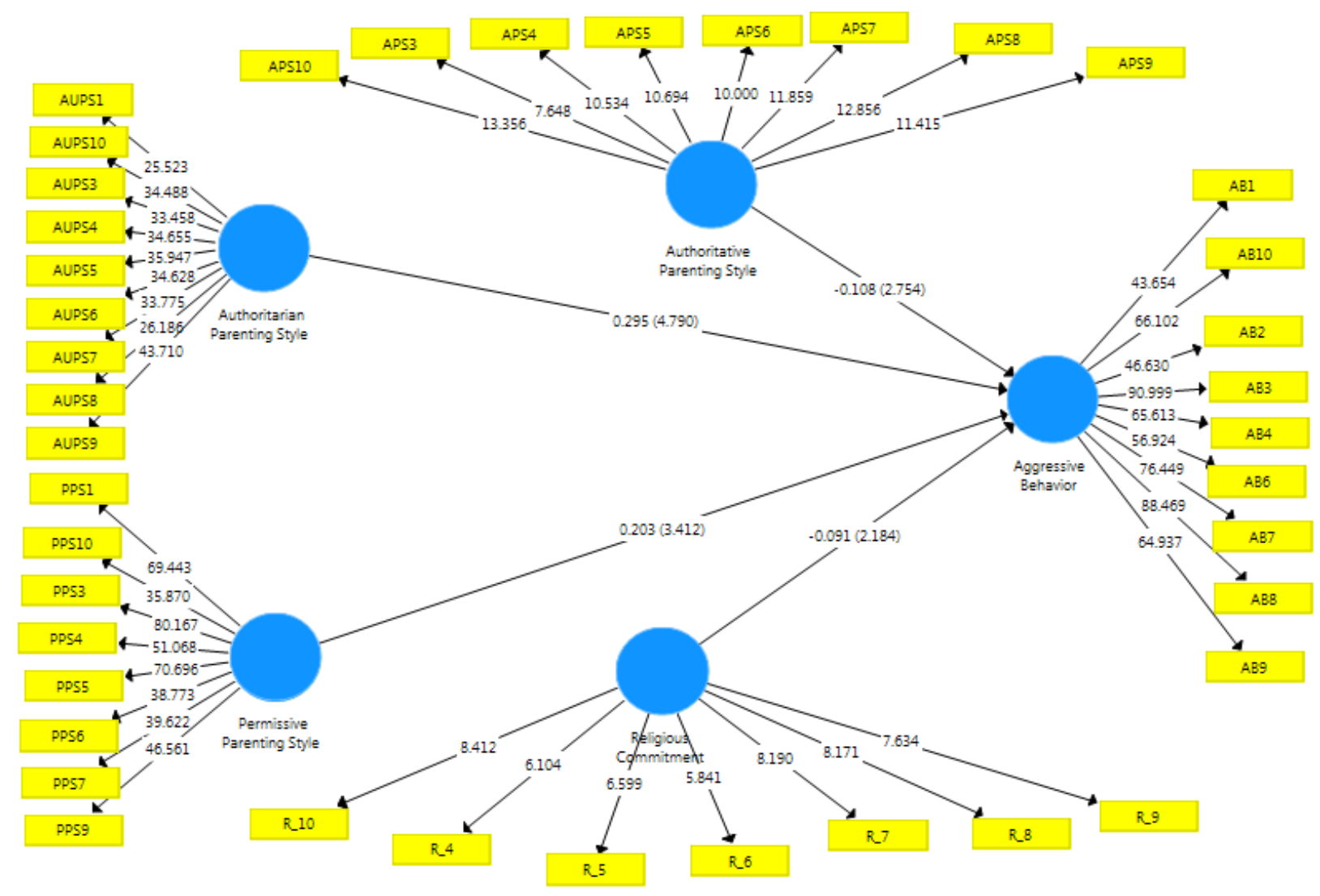

Figure 3: Structure Equation Modeling

\subsection{Discussion and Conclusion}

The principle aim of this study was to identify the influence of parenting styles (authoritative, authoritarian, permissive) and religious commitment in developing of aggressive behavior among youth of south Punjab Pakistan. Youth antisocial aggressive behavior is considered one of the most pressing public health issues, which is harmful for individuals, community, society and costly to the family institution as well (Ashraf et al., 2019). Findings of this study are prior study Ojo (2015) which reported environment behind the closed door such as parent-child rapport, parental use of vulgar language, domestic quarrel, poverty, homelessness and broken families and more importantly bad parental behavior can increase the chances of anti-social aggressive behavior among children. Consequently, findings of present study revealed that authoritarian and permissive parenting styles have significant positive relationship with aggressive behavior. These findings are aligned with prior to recent studies of Kuppens et al. (2009), Gomez-Ortiz et al. (2014), Clark et al. (2015) and Ashraf et al. (2019). The outcomes of these studies are revealed that hash, parental restrictions, superfluous demanding, punitive and lenient parenting practices that triggered adolescents' behavioral problems. Furthermore, Sangawi, Adams and Reissland (2015) cross-culturally reviewed 21 previous studies and concluded that authoritarian parenting style would be resulted into child's behavioral problems in later life.

When it comes to authoritative parenting style researcher Batool (2013) found authoritative parenting as negative predictor of child's behavioral manifestation (Hoskins, 2014). The findings of this study shown that authoritative parenting style has significant negative relationship with aggressive behavior. The findings of this study aligned with the previous studies (Ashraf et al., 2019). Likewise, religious commitment has been found to be negatively associated with antisocial aggressive behavior of youth. These findings are consistent with western contextual study of Massarwi, Kassabri and Eseed (2019) conducted in Israel which found the significant negative role of religious commitment in decreasing deviancy. In such way, we can say religious values give intervention strategies to those institutions which are working for normalizing the aggressive behavior to normal positive behavior. 
By following deductive approach in quantitative studies results are consistent with the assumptions of Hirschi's theory of social control based on attachment, involvement, commitment and belief. Attachment with parents, commitment to vision, involvement in struggling to achieve settled aspiration and belief in religion can prevent youngsters to adopt aggressive behavior. Results of present study is aligned with these assumptions and consistent with previous literature (Brannigan et al., 2002; Hinrich et al., 2005; Chapple, 2003; Kawabata et al., 2011; Massarwi, Kassabri\& Eseed,2019; Johnson et al. 2001; Resnick et al., 2004).) Which had tested this theory found this theory reliable cross-culturally. The concluding remarks about the findings of present study revealed that authoritarian and permissive parenting styles are found potential factors increasing aggressive behavior of youth, contrary, authoritative parenting style and religious commitment negatively associated with antisocial aggressive behavior.

\subsection{Practical Implications}

This research would be helpful for policy makers, sociologists, psychologists, religious scholarsand practitioner to promote polices and setting that would be in support of authoritative parenting style in out Pakistani context. This research would provide guidance to the parents to understand the importance of their rapport in front of their child for developing effective behavioral manifestation of youth. This study will not only help family and educational institutions but also helps those institutes which are offering programs to normalize behavior of youth by giving logical religious reasoning to them. Keeping consideration on the findings of the study this research suggested that future studies should be conducted to understand the role of peer victimization, inflation, frustration, discrimination in educational institutes and aggressive behavior in Pakistani context.

\section{REFERENCES}

Alizadeh, S., Talib, M. B. A., Abdullah, R., \&Mansor, M. (2011). Relationship between parenting style and children's behavior problems. Asian Social Science, 7(12), 195-200.

Anderson, J. C., and D.W. Gerbing, "Structural equation modelling in practice: A review and recommended two-step approach", Psychological Bulletin, Vol. 103, No. 2: 411-423, 1988.

Ashraf, M. U., Asif, M., Iqbal, M. M. A., \&Warraich, I. A. (2019). Role of Socioeconomic Status and Parenting Practices in construction of Violent
Behavior among Youth: A Study from South Punjab, Pakistan. Pakistan Journal of Social Sciences (PJSS), 39(2).

Bandura, A. (1989). Human agency in social cognitive theory. American psychologist, 44(9), 1175.

Barclay, D., Higgins, C. and Thompson, R. (1995) 'The partial least squares (PLS) approach to casual modeling: personal computer adoption and use as an illustration', Technology Studies, Hypothesis Testing, Google Scholar, Vol. 2, pp.285-309.

Batool, S. S. (2013). Lack of adequate parenting: A potential risk factor for aggression among adolescents. Pakistan Journal of Psychological Research, 28(2).

Baumrind, D. (1966). Effects of authoritative parental control on child behavior. Child development, 887-907.

Boxer, P., \& Goldstein, S. E. (2012). Treating juvenile offenders: Best practices and emerging critical issues. In Handbook of juvenile forensic psychology and psychiatry (pp. 323-340). Springer, Boston, MA.

Brannigan, A., Gemmell, W., Pevalin, D. J., \& Wade Terrance, J. (2002). Self-control and social control in childhood misconduct and aggression: The role of family structure, hyperactivity, and hostile parenting. Canadian J. Criminology, 44, 119.

Buri, J. R. (1991). Parental authority questionnaire. Journal of personality assessment, 57(1), 110-119.

Centers for Disease Control and Prevention. (2017). Youth Risk Behavior Surveillance-United States, 2013. Retrieved from http://nccd.cdc.gov/youthonline/App/Defa ult.aspx.

Chapple, C. L. (2003). Examining intergenerational violence: Violent role modeling or weak parental controls? Violence and

Victims, 18(2), 143-162.

Clare, H. (2006). Antisocial behaviour: Gale encyclopedia of children health. New York. Gale Group.

Clark, C. M., Dahlen, E. R., \& Nicholson, B. C. (2015). The role of parenting in relational aggression and prosocial behavior among emerging adults. Journal of Aggression, Maltreatment \& Trauma, 24(2), 185-202.

Desmond, S. A., Soper, S. E., \& Kraus, R. (2011). Religiosity, peers, and delinquency: Does religiosity reduce the effect of peers on 
delinquency? Sociological spectrum,31(6), 665 694.

Fornell, C., and D.F. Larcker, "Evaluating structural equation models with unobservable variables and measurement error", Journal of Marketing Research, Vol. 18, No. 1: 39-50, 1981.

Gini, G., \&Pozzoli, T. (2013). Bullied children and psychosomatic problems: A metaanalysis. Pediatrics, 132(4), 720-729.

Gómez-Ortiz, O., Del Rey, R., Casas, J. A., \&

Ortega-Ruiz, R. (2014). Parenting styles and bullying

involvement/Estilosparentalesimplication en bullying. Cultura y Educación, 26(1), 132158.

Gray, M. R., \& Steinberg, L. (1999). Unpacking authoritative parenting: Reassessing a multidimensional construct. Journal of Marriage and the Family, 574-587.

Hair, J. F., G.T.M. Hult, C.M. Ringle, and M. Sarstedt, A Primer on Partial Least Squares Structural Equation Modeling (PLS-SEM), 2nd Edition. Thousand Oaks: Sage, 2017.

Hair, J. F., Ringle, C. M., \&Sarstedt, M. (2013). Editorial-partial least squares structural equation modeling: Rigorous applications, better results and higher acceptance. Long Range Planning, 46(1-2), 1-12.

Hair, J.F., Ringle, C.M. and Sarstedt, M. (2011) 'PLS-SEM: indeed a silver bullet', The Journal of Marketing Theory and Practice, Vol. 26, No. 2, pp.139-152.

Henrich, C. C., Brookmeyer, K. A., \& Shahar, G. (2005). Weapon violence in adolescence: Parent and school connectedness as protective factors. Journal of Adolescent Health, 37(4), 306-312.

Henseler, J., C.M. Ringle, and M. Sarstedt, "A new criterion for assessing discriminant validity in variance-based structural equation modelling", Journal of the Academy of Marketing Science, Vol. 43, No. 1: 115-135, 2015.

Hirschi, T. (1969). Key idea: Hirschi's social bond/social control theory. Key Ideas in Criminology and Criminal Justice, (1969), 55-69.

Hoskins, D. H. (2014). Consequences of parenting on adolescent outcomes. Societies, 4(3), 506531.

Johnson, B. R., Jang, S. J., Larson, D. B., \& De Li, S. (2001). Does adolescent religious commitment matter? A reexamination of the effects of religiosity on delinquency. Journal of Research in Crime and Delinquency, 38(1), 22-44.
Kawabata, Y., Alink, L. R., Tseng, W. L., Van Ijzendoorn, M. H., \& Crick, N. R. (2011). Maternal and paternal parenting styles associated with relational aggression in children and adolescents: A conceptual analysis and meta-analytic review. Developmental review, 31(4), 240-278.

Khan, A. A., Malik, J. A., Musharraf, S., \& Lewis, C. A. (2019). Parents' prejudices or own religious orientation of Pakistani children: determinants of achievement-related prejudices for opposite gender and sect and their relation with mental health. Journal of Beliefs \& Values, 1-15.

Kline, R. (2011) Convergence of Structural Equation Modeling and Multilevel Modeling, Koenig, H. G., King, D. E., \& Carson, V. B. (2012). Coping with stress. Handbook of religion and health, 2nd edn. Oxford University Press, NewYork, 74-93.

Krejcie, R. V., \& Morgan, D. W. (1970). Determining sample size for research activities. Educational and psychological measurement, 30(3), 607-610.

Kuppens, S., Grietens, H., Onghena, P., \&Michiels, D. (2009). Associations between parental control and children's overt and relational aggression. British Journal of Developmental Psychology,27(3), 607623.

Massarwi, A. A., Khoury-Kassabri, M., \&Eseed, R. (2019). The correlation between delinquent peers and perpetration of serious physical violence: religiosity as a protective factor. Child Indicators Research, 12(6), 2051-2065.

Miklikowska, M. (2016). Like parent, like child? Development of prejudice and tolerance towards immigrants. British Journal of Psychology, 107(1), 95-116.

Mulvaney, M. K., \&Mebert, C. J. (2007). Parental corporal punishment predicts behavior problems in early childhood. Journal of family psychology, 21(3), 389.

Ojo, I. O. (2015). Causes and Prevalence of Antisocial Behaviour among Students with Hearing Impairment in Ibadan, Nigeria. Journal of Education and Practice, 6(28), 38-43.

Orpinas, P., \&Frankowski, R. (2001). The Aggression Scale: A self-report measure of aggressive behavior for young adolescents. The Journal of Early Adolescence, 21(1), 50-67.

Pakistan Social and Living standard measurement(2013-14). Retrieved From http://www.pbs.gov.pk. 
Pirutinsky, S. (2014). Does religiousness increase self-control and reduce criminal behavior? A longitudinal analysis of adolescent offenders. Criminal Justice and Behavior, 41(11), 1290-1307.

Podsakoff, P.M., S.B. MacKenzie, and N.P. Podsakoff, "Sources of method bias in social science research and recommendations on how to control it", Annual Review of Psychology, Vol. 65: 539-569, 2012.

Punjab Bureau of Statistics. (2018). Crime and Education.

http://bos.gop.pk/system/files/pb\%202017 .pdf.

Resnick, M. D., Ireland, M., \&Borowsky, I. (2004). Youth violence perpetration: what protects? What predicts? Findings from the National Longitudinal Study of Adolescent Health. Journal of adolescent health, 35(5), 424-e1.

Ringle, C. M., S. Wende, and J-M. Becker, "SmartPLS 3. Bönningstedt: SmartPLS", Accessed May 15, 2018. http://www.smartpls.com, 2015.

Rizvi, S. F. I., \& Najam, N. (2015). Emotional and behavioral problems associated with parenting styles in Pakistani adolescents. VFAST transactions on education and social sciences, 8(2).

Sanders, P. W., Allen, G. K., Fischer, L., Richards, P. S., Morgan, D. T., \& Potts, R. W. (2015). Intrinsic religiousness and spirituality as predictors of mental health and positive psychological functioning in Latter-day Saint adolescents and young adults. Journal of religion and health, 54(3), 871-887.

Sandstrom, M. J. (2007). A link between mothers' disciplinary strategies and children's relational aggression. British Journal of Developmental Psychology, 25(3), 399-407.

Sangawi, H., Adams, J., \&Reissland, N. (2015). The effects of parenting styles on behavioral problems in primary school children: a cross-cultural review. Asian social science., 11(22), 171-186.

Shagufta, S., Boduszek, D., Dhingra, K., \& KolaPalmer, D. (2015). Latent classes of delinquent behavior associated with criminal social identity among juvenile offenders in Pakistan. Journal of Forensic Practice, 17(2), 117-126.

Smack, A. J., Kushner, S. C., \& Tackett, J. L. (2015). Child personality moderates' associations between parenting and relational and physical aggression. Journal of Aggression, Maltreatment \& Trauma, 24(7), 845-862.
Stevens, G. W., Vollebergh, W. A., Pels, T. V., \&Crijnen, A. A. (2007). Parenting and internalizing and externalizing problems in Moroccan immigrant youth in the Netherlands. Journal of youth and adolescence, 36(5), 685-695.

Stone, M. (1974). Cross- validatory choice and assessment of statistical predictions. Journal of the Royal Statistical Society: Series B (Methodological), 36(2), 111-133.

Stormshak, E. A., Bierman, K. L., McMahon, R. J., \&Lengua, L. J. (2000). Parenting practices and child disruptive behavior problems in early elementary school. Journal of clinical child psychology, 29(1), 17-29.

U.S. Department of Education, National Center for Education Statistics (2016). Washington, DC. Retrieved [date] from http://nces.ed.gov/pubsearch.

Worthington Jr, E. L., Wade, N. G., Hight, T. L., Ripley, J. S., McCullough, M. E., Berry, J. W., . . . O'connor, L. (2003). The Religious Commitment Inventory--10: Development, refinement, and validation of a brief scale for research and counseling. Journal of Counseling Psychology, 50(1), 84. New York: 9. 